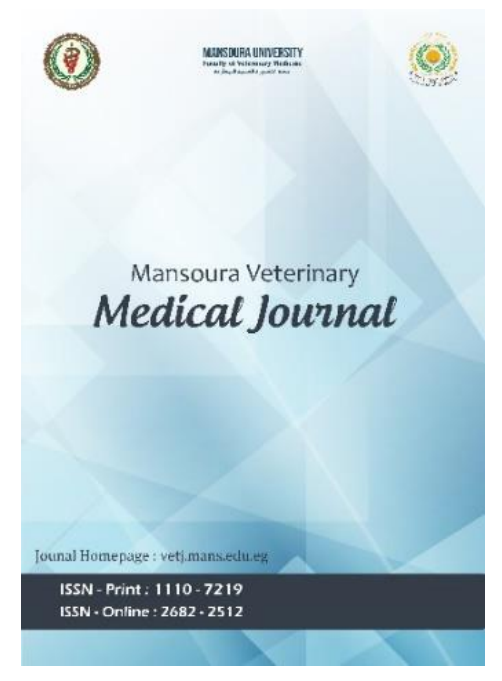

\title{
Ameliorative effects of Pergamum harmala seed extract on obese diabetic rats
}

Neveen Magdy, Mohamed Salama, Youssef Alsaedy, Gehad ElSayed

To cite this article: Neveen Magdy, Mohamed Salama, Youssef Alsaedy, Gehad El-Sayed. Ameliorative effects of Pergamum harmala seed extract on obese diabetic rats. Mansoura Veterinary Medical Journal 2020; 21, 3: 116-120.

To link to this article: $h$ ttps://doi.org/10.35943/mvmj.2020.21.319

Published online: 29 September 2020

Submit your article to this journal

CrossMark data 


\title{
Ameliorative effects of Pergamum harmala seed extract on obese diabetic rats
}

\author{
Neveen Magdy ${ }^{1}$, Mohamed Fouda Salama ${ }^{1}$, Youssef Yahia Alsaedy², Gehad Ramadan El-Sayed ${ }^{1}$ \\ ${ }^{1}$ Depa rtment of Biochemistry and Chemistry of Nutrition, Faculty of Veterinary Medicine, Ma nsoura University, Mansoura 35516, \\ Egypt. \\ ${ }^{2}$ Department of Physiology, Faculty of Veterinary Medicine, Mansoura University, Mansoura 35516, Egypt.
}

\section{ARTICLE HISTOR}

Received: 09.06.2020

Revised: 01.07.2020

Accepted: 02.07.2020

Address correspondence to Neveen Magdy; Tel: +2001003273454; E-mail: Email:adel33415347@gmail.com; ORCID ID: 0000-0002-7531-3509

\section{ABSTRACT}

\begin{abstract}
Objective: To explore the potential antidiabetic activity of methanolic extract of Harmal seeds in obesediabetic rats.

Design: Randomized controlled experimental study.

Animals: Forty male Sprague Dawley rats.

Procedures: The $P$. harmala seeds methanolic extract was prepared and orally administered at two doses of 150 and $250 \mathrm{mg} / \mathrm{kg}$ to two groups of streptozotocin-induced diabetic rats. Two additional control groups were used as healthy control and obese-diabetic control groups. Animals were euthanized after 8 weeks of experimental period, blood and tissue samples were collected. Liver tissue samples were used to determine antioxidant and oxidative stress markers; while those from adipose tissue were used for estimation of PPAR gamma expression.

Results: Supplementation of $P$. harmala methanolic extract with both doses (150 and $250 \mathrm{mg} / \mathrm{kg}$ ) to diabetic rats (G3 and G4) significantly reversed the observed alterations in the levels of blood glucose, cholesterol, triglyceride, LDL, malondialdehyde (MDA), reduced glutathione (GSH), and superoxide dismutase $(S O D)(P<0.05)$. In addition, the downregulation of PPAR gamma expression in diabetic rats (G2) was also restored in rats (G3 and G4) supplemented with P. harmala methanolic extract.

Conclusion and clinical relevance: Our finding revealed that Harmal seed extract has a potent antidiabetic activity in streptozotocin-induced diabetic rats that can be used as a dietary supplement by diabetic patients.
\end{abstract}

Keywords: Obesity; Type 2 Diabetes; Methanolic extract of $P$. harmala seed.

\section{INTRODUCTION}

Obesity is a chronic meta bolic disease that occur due to exces sive fat a ccumulation leading to energy imbalance that is associated with chronic disorders like diabetes mellitus type 2, cancer and heart diseases [1]. The obesity complications usually occur since adipose ti ssue regarded as endocrine organ that secretes circulating hormones, such as adi pokines and cytokines (leptin, tumor necrosisfactor (TNF$\alpha$ ), adiponectin, interleukin 6 (IL-6).) [2].

Obesity is combined with an elevated risk of insulin resistance and diabetes type 2 , as increased free fatty acids (FFA) concentrations inhibits insulin signaling and GLUT-4 sti mulated muscle gl ucose uptake leading to suppression of glycogen synthesis and glycolysis [3].

Increased FFA in liver leads to hyperglycemia by reversing the effects of insulin on production of endogenous glucose and changing in insulin sensitivity [4]. Insulin resistance develops mainly in skeletal muscle which is the most contributor to resistance in type 2 dia betes mellitus [5].

In recent years, obesity rates have continued to increase rapidly with increased incidence of type2 diabetes. Moreover, various studies have documented that management obes ity can del ay the onset of type 2 dia betes [6]. The use of herbal medicine has been proven to be effective in the treatment of many diseases with minimal side effects, Peganum harmala is one of natural plants that has widely been used as a medicinal plant in south Asia, Middle East and North Africa. It is recognized as Harmal, Syrian rue or Wild rue [7].

Harmala belongs to zygophylaceae family which has a wide range of medicinal properties due to pres ence of betacarboline alkaloids as harmine, harmaline, harmalol and harmol [8]. Beta-carboline which present in many natural medicinal plants has drawn attention in recent studies due to their activities as anti-tumor and antidiabetic, as they inhibit glucose absorption in the gut, enhances glucose uptake and up-regulation of glucose transports, increase releasing of adiponectin [9].

Recent years of study has explained various therapeutic and pharmacological activities of Harmal and its active alkaloids especially Harmine (that is found in the seeds of Harmal), which act as a cell- type-specific regulator of peroxisome proliferator-activated receptor (PPARY), Harmine induce the expression of PPARy that acts as a master regulator of adipogenesis [10]. 
The expression of PPARy in adipose tissue opens the door to develop novel metabolic drugs as it regulates storage of fatty acids and glucose metabolism. PPARy is expressed mainly in adipose tissue, in two is oforms in the human and rats: PPAR- $\gamma 1$ (found in nearly all tissues except muscle) and PPAR- $\gamma 2$ (mostly found in intestine a nd adipose tissue). Therefore PPAR gamma could be used as a therapeutic ta rget to antagonize obesity-associated insulin resistance[11].

The purpose of the current study was to evaluate the potential protective effect of P.harmala seed methanolic extract on blood glucose level, lipid profile, a ntioxidative stress markers and PPAR-gamma expression in obesediabetic rats.

\section{MATERIALS AND METHODS}

\subsection{Chemicals}

Streptozotocin, (STZ) (Sigma Aldrich, UK) was used for experimental induction of diabetes in rats, dissolved in 0.1 M citrate buffer. Thiopental sodium (El-Gumhoria Co., Egypt) was used for anesthesia. RNA later was purchased form (Sigma Aldrich, UK) and used for tissue samples preservation. Methanol was purchased from (El-Gumhoria Co, Egypt) and used for preparation of peganum harmala seed extract.

\subsection{Animals and samples collection}

This experiment was implemented on 40 male rats; the animals were purchased from Medical Experimental Research Center (MERC) at Fa culty of Medi cine, Mansoura University. Rats were housed in standard laboratory conditions and they had access to water and diet (formulated in MERC) ad libitum. The animals were divided into 4 equal groups (10 rats each). Group 1 (control group) was fed on normal ration and gavaged two $\mathrm{ml}$ of saline for three weeks. Group 2 (control obese-diabetic) was fed on high fat diet to induce obesity then experimental diabetes was induced by single dose of STZ $(35 \mathrm{mg} / \mathrm{kg})$ intraperitonral; 48 hours after STZ injection the fasting blood glucose level was measured and a nimals with levels more than $180 \mathrm{mg} / \mathrm{dl}$ were regarded as diabetic, then gavaged two $\mathrm{ml}$ of saline for three weeks. In group 3 (obese-diabetic treated group1) diabetes was induced in obese rats as in group 2, and the rats received a daily oral dose of $P$. harmala extract (150 $\mathrm{mg} / \mathrm{kg}$ ) by gavage. In group 4, diabetes was induced as in group 2, and rats were gavaged daily with $P$. harmala methanolic extract at a dose of $250 \mathrm{mg} / \mathrm{kg}$ for 3 weeks. At the end of 8 th week, rats were euthanized I/P under thiopental sodium anesthesia $(40 \mathrm{mg} / \mathrm{kg})$ body weight. Samples of blood were then collected by cardiac puncture and were taken in tubes with and without anticoagulant. Plasma glucose concentration was determined using commercial available kits (Sigma Aldrich, UK) the collected blood was transmitted into a Sodium Fluoride-containing tube to separate plasma; the tube was then centrifuged at $4000 \mathrm{rpm}$ for $15 \mathrm{~min}$. Plasma was then transmitted into a clean, dry, labeled tube and stored at $-20 \mathrm{C}^{\circ}$ until required for the measurement of glucose level. Animals with blood glucose level > $280 \mathrm{mg} / \mathrm{dl}$ were regarded diabetic. The biochemical parameters such as insulin, triglyceride, HDL-c, total cholesterol and LDL-C were determined using commercial a vailable kits (Sigma Aldrich, UK), the samples of blood were combined in a plain tubes for serum separation, the tubes were left at room temperature in a vertical position then centrifuged at $3000 \mathrm{rpm}$ for $15 \mathrm{~min}$. Serum was then tra nsferred into a clean, dry, labeled tube and stored at $-20 C^{\circ}$ until required for the measurement. After blood samples collection, animals were dissected to collect liver tissue samples that were stored in clean, dry eppendorf tubes at $-80 \mathrm{C}^{\circ}$ with Phosphate-buffered saline (PBS), and used for the measurement of the oxidative stress and antioxidant parameters. Serum malondialdehyde (MDA) level was considered as a n end product of lipid peroxidation and measured by the thiobarbituric acid (TBA) reaction method (kei,1978), and was obtained from Sigma Chemical Company. Reduced glutathione (GSH) concentration and superoxide dismutase (SOD) activity measured using available kits (Sigma Aldrich, UK) by using liver tissue samples stored in clean tubes at $-80 \mathrm{C}^{\circ}$ with PBS. Adipose tiss ue samples were also collected, stored in RNA later at- 80 $\mathrm{C}^{\circ}$ and us ed for RT-PCR a nalysis of PPAR-gamma expression.

\subsection{Gene expression analysis of PPAR gamma}

Total RNAs were extracted using RNAMini Kit (RNeasy, 74104, Qiagen). Equivalents of $2(\mu \mathrm{g})$ of RNA were transferred into cDNA, using instructional manual. cDNA was synthesized using high capacity cDNA Reverse transcription kit (Cat. No. EP0441, Thermo Fisher) to act as a template for quantitative PCR by using Quantitect SYBR green PCR kit (Cat. No. 204141, Qiagen). The PCR reaction was performed using Pikoreal, Thermoscientific, USA and started with an initial denaturation step of $94^{\circ} \mathrm{C}$ for 5 minutes. A forty cycles of PCR reaction was performed that initiated with denaturation step at $94^{\circ} \mathrm{C}$ for 15 seconds, a nnealing step at $55^{\circ} \mathrm{C}$ for 30 seconds using s pecific primers for PPAR gamma and GAPDH (as a house keeping gene; Table 1). Finally, an extension step was performed at $72^{\circ} \mathrm{C}$ for 30 seconds for completion of the amplification step. The strata gene $\mathrm{mx}$ $3005 p$ software was used to cal culate ct values. The ct of each sample was compared with the control group according to the " $\Delta \Delta C t^{\prime}$ method to es timate the relative expression of PPAR gamma [12].

\subsection{Statistical analysis}

Data was analyzed using statistical software (Graphpad prism for wind ows version 7.0; Graph pad software, Inc., San Diego, CA, USA) program. One- way ANOVA with post hoc LSD comparison test was used to detect significant differences among different groups. Data was presented as mean and standard error of mean [13].

\section{RESULTS}

3.1. P. harmala extract restores elevated blood glucose level in obese diabetic rats 
The obese-diabetic group (G2) revealed a significant increase in blood glucose levels when compared with the control group (G1). Treatment of groups 3 and 4 with P. harmala methanolic extract significantly reduced blood glucose levels; in group 3 blood glucose level were similar to those of control non diabetic group (G1). Table (2) $(P<0.05)$.

\subsection{P. harmala extract antagonizes insulin resistance in} diabetic rats

Insulin level was significantly increased in diabetic group (G2) when compared with normal control group (G1). Treatments of rats with $P$. harmala extract with both doses (150 and $250 \mathrm{mg} / \mathrm{kg}$ ) in groups 3 and 4 significantly decreased insulin levels compared to obese-diabetic group (G2) as shown in Table (2) $(P<0.05)$.

\subsection{P. harmala extract normalizes altered lipid profile in} diabetic rats

Administration of $P$. harmala extract to groups 3 and 4 caused significant decrease in the total cholesterol levels, triacylglycerol (TAG), and LDL-C when compared to the dia betic group (G2). On the other hand, HDL-C level revealed a significant increase in the treated groups (G3 and G4) compared to obese diabetic group (G2) as shown in table (2).

\subsection{P. harmala extract antagonizes oxidative stress in} diabetic rats

Obese-diabetic rats in $\mathrm{G} 2$ showed significantly increased MDA levels and decreased GSH concentration and SOD activity compared to control group (G1). Treatment of dia betic rats with $P$. harmala ( 150 and $250 \mathrm{mg} / \mathrm{kg}$ ) in $\mathrm{G} 3$ and G4 caused a significant reduce in MDA levels compared to obese diabetic group (G2); however, the MDA level s were significantly higher than those of control group G1. The treated groups with $P$. harmala extract with both doses showed a significant increase in GSH concentration and SOD activity compared to obes e diabetic group (G2) as shown in table (3).
Table1. List of primer pairs used in experiment.

$\begin{array}{lll}\text { Gene } & \text { Primer sequence }\left(5^{\prime}-\mathbf{3}^{\prime}\right) & \text { Reference } \\ \text { GAPDH } & \begin{array}{l}\text { ATGACTCTACCCACGGCAAG } \\ \text { CTGGAAGATGGTGATGGTT }\end{array} & {[14]} \\ \text { PPARY } & \begin{array}{l}\text { TATCATAAATAAGCTTCAATCGGATGGTTC } \\ \text { GAGATGGAATTCTGGCCACCAACTTCGG }\end{array} & \text { [15] } \\ & & \end{array}$

GAPDH: Glyceraldehyde-3-Phosphate Dehydrogenase is the house keeping gene.

PPARY: Peroxisome Proliferator-Activated Receptor Gamma.

\section{5 .P. harmala extract induces PPAR- $\gamma$ expression}

As shown in figure 1, the obese diabetic group showed a significant down-regulation of PPAR-gamma expression compared to control group. Moreover, treatment of rats with P. harmala extract was associated with a significant upregulation of PPAR-gamma expression compared to obese diabetic group (G2)

Table 3. MDA, GSH and SOD in liver tissue of rats with experimentally induced diabetes and treated with $P$. harmala seed extract.

\begin{tabular}{llll} 
Groups & $\begin{array}{l}\text { MDA } \\
\text { (nmol/g.Tissue) }\end{array}$ & $\begin{array}{l}\text { GSH } \\
\text { (mg/g.Tissue) }\end{array}$ & $\begin{array}{l}\text { SOD } \\
\text { (U/gm) }\end{array}$ \\
\hline G1 & $52.5 \pm 4.5^{c}$ & $107.4 \pm 2.539^{a}$ & $119.8 \pm 5.3^{a}$ \\
G2 & $129 \pm 6.2^{a}$ & $58.84 \pm 3.343^{c}$ & $27.7 \pm 2.4^{c}$ \\
G3 & $86.48 \pm 4.7^{b}$ & $92.62 \pm 5.774^{\text {ab }}$ & $76.7 \pm 6.6^{b}$ \\
G4 & $75.5 \pm 3.3^{b}$ & $75.82 \pm 4.455^{\text {bc }}$ & $58.6 \pm 4.5^{b}$
\end{tabular}

Means in the same column with different superscript letters are differing significantly $(P<0.05)$.

G1: Normal control group; G2: Obese diabetic group; G3: Obese diabetic-treated group with (150 mg/kg) P.harmala extract; G4: Obese diabetic- treated group with $(250 \mathrm{mg} / \mathrm{kg}) \quad$ P.harmala extract.

Table2. Effect of $P$. harmala seed methanolic extract on glucose, insulin, lipid profile in rats with experimentally induced diabetes.

\begin{tabular}{|c|c|c|c|c|c|c|}
\hline Groups & $\begin{array}{l}\text { Glucose } \\
\text { (mg/dl) }\end{array}$ & $\begin{array}{l}\text { Insulin } \\
\text { (ng/dl) }\end{array}$ & $\begin{array}{l}\text { Cholesterol } \\
(\mathrm{mg} / \mathrm{dl})\end{array}$ & $\begin{array}{l}\text { Triglyceride } \\
\text { (mg/dl) }\end{array}$ & $\begin{array}{l}\text { LDL } \\
(\mathrm{mg} / \mathrm{dl})\end{array}$ & $\begin{array}{l}\mathrm{HDL} \\
(\mathrm{mg} / \mathrm{dl})\end{array}$ \\
\hline \multirow[t]{2}{*}{ G1 } & $117.0 \pm$ & $0.2516 \pm$ & $125.02 \pm$ & $90.9 \pm$ & $64.52 \pm 9$ & $54.18 \pm$ \\
\hline & $1.913^{c}$ & $0.0064^{b}$ & $3.9^{b}$ & $10.5^{b}$ & $.6^{\mathrm{ab}}$ & $2.134^{a}$ \\
\hline \multirow[t]{2}{*}{ G2 } & $328.2 \pm$ & $0.4790 \pm$ & 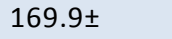 & $148.3 \pm$ & $84.89 \pm$ & $17.87 \pm$ \\
\hline & $19.45^{a}$ & $0.0057^{a}$ & $13.7^{a}$ & $12.3^{a}$ & $12.03^{a}$ & $1.712^{\mathrm{c}}$ \\
\hline G3 & $\begin{array}{l}127.6 \pm \\
2.04^{b, c}\end{array}$ & $\begin{array}{l}0.2762 \pm \\
0.018^{b}\end{array}$ & $\begin{array}{l}116.6 \pm \\
2.7^{b}\end{array}$ & $\begin{array}{l}78.7 \pm \\
2.9^{b}\end{array}$ & $\begin{array}{l}45.85 \pm \\
3.43^{b}\end{array}$ & $\begin{array}{l}47.93 \pm \\
2.17 a, b\end{array}$ \\
\hline G4 & $\begin{array}{c}166.6 \pm \\
7.39^{b}\end{array}$ & $\begin{array}{l}0.3010 \pm \\
0.024^{b}\end{array}$ & $\begin{array}{l}121.8 \pm \\
4.9^{b}\end{array}$ & $\begin{array}{l}94.7 \pm \\
2.9^{b}\end{array}$ & $\begin{array}{l}50.97 \pm \\
5.17^{b}\end{array}$ & $\begin{array}{l}40.51 \pm \\
1.91^{b}\end{array}$ \\
\hline
\end{tabular}

G1: Normal control group; G2: Obese diabetic group; G3: Obese diabetic- treated group with (150 mg/kg) P.harmala extract; G4: Obese diabetic- treated group with $(250 \mathrm{mg} / \mathrm{kg})$ P.harmala extract.

Means in the same column with different superscript letters are differing significantly $(P<0.05)$. 


\section{DISCUSSION}

Obesity and type 2 diabetes mellitus relationship is well established that is related with the development of insulin resistance, a condition which based on the truth that $\beta$-cells of pancreas are impaired leading to deficiency of blood glucose level [16]. The control of overweight and obesity is the key to reduce occurance of diabetes type 2 [17], as obesity is the main cause for many metabolic diseases. Therefore, obesity control and management can reduce incidence of diabetes type 2 and help in treatment [18]. Intensive lifestyle, physical exercise and now therapeutic use of natural plants can help in weight loss in absence of pha rmacological therapy [19]. In recent yea rs, natural plants have extensively been used for the treatment of many dis eases instead of chemical and pharmacological drugs with their side effects on general health. Peganum harmala is one of natural plant that is rich in $\beta$-carboline and quinazoline alkaloids that are enriched in many parts of the plant, including capsule, fruits and seeds [8]. The antidiabetic effect of this harmala has been illustrated in previous studies with reduced blood glucose level; however, the hypoglycemic effect was lost when used at high doses [20]. The harmine is the most important alkaloids which have a role in regulating PPARy expression, which act as a regulator of a dipogenesis and mimic the adipocyte gene expression and improve insulin sensitivity [10].

In the present study, we aimed to evaluate the effect of $P$. harmala seed extract in obese diabetic rats. From previous studies, $P$. harmala has been shown to be as functional as the oral hypoglycemic drug metformin in lowering glucose level. The hypoglycemic effect of the harmal seed extract could be attributed to its content of several alkaloids as $\beta$ ca rboline derivatives [8]. Results of this study clearly showed that the methanolic Peganum harmala seed extract, significantly reduced glucose level in obese diabetic rats when administered at two different doses (150 and 250 $\mathrm{mg} / \mathrm{kg}$ body weight). The metha nolic extract was effective in decreasing blood levels of gl ucose in STZ-induced diabetic rats, and certainly, the most effective dose was $150 \mathrm{mg} / \mathrm{kg}$ (Group 3) confirming its anti-diabetic effects as previously stated [7]. Insulin levels in obese diabetic rats were significantly elevated, such an increase is related with el evated the reason for developing insulin resistance and diabetes type 2 . Treatment of diabetic rats with $P$. harmala extract in groups 3 and 4 showed significantly lower insulin levels compared to non-treated diabetic rats, suggesting its role in antagonizing insulin resistance. However, it was reported that Harmal seed extract has no insulin secretion activity; therefore, the possible hypoglycemic effect could be mediated by the effects on glucose absorption and utilization [21].

One of the beneficial effects of Harmal is that it has the abi lity to reduce the li pid peroxidation and oxidative stress, the a ntihyperlipidemic effect of Harmal could be referred to the presence of alkaloids as harmaline and harmine, which have significant free radical scavenging ability and ina ctivates lipid peroxidation [22]. Oral administration of $P$. harmala seed extract caused a significant decrease in the total cholesterol levels, triglyceride and LDL, with a significant elevate in HDL levels compared to untreated obese-diabetic rats. The antioxidant effect of Harmal may refer to the presence of phenolic compounds like flavonoids and tannins present in methanolic extract [23]. Our results revealed a significant reduce in lipid peroxidation levels and a significant el evate in antioxidants as (GSH and SOD) in P.harmala treated groups compared with obese-diabetic group. Further confirming the anti-oxidative capacity of peganum harmala.

Interestingly, Harmine that is the major constituent of peganum harmala has been shown to upregulate the expression of PPARY gene through the inhibition of Wnt signaling pathway [24]. The PPAR gamma plays an important role in a dipogenesis a nd regulates the metabolism of lipid in a di pocyte. Our results showed a significant induction in the relative PPARY expression in P.harmala s eed extract-treated diabetic rats when compared with untreated obese-diabetic group. Our finding suggests that $P$. harmala induced PPAR gamma expression and also restore lipid and glucose metabolism indiabeticanimals lea ding to hypoglycemia.

This results were in agreements with As garpanah et al., [9] who reported that P.harmala has antidiabetic and antihyperlipidemic activities, also has the ability to reduce oxidative stress and has hepatoprotective effects due to presence of $\beta$-carboline which have many pharmacological activities.

\section{Conclusion}

Results from the present study demonstrate that the methanolic extract of Harmal seed has antidiabetic and antioxidant effects by lowering blood glucose levels and restoring oxidative stress markers in diabeti c rats. Moreover, $P$. harmala metha nolic extract induces the expression of the adipogenic transcription factor PPARy and promote a dipocyte differentiation and improve glucose tolerance and insulin sensitivity. Therefore, harmala can be used as a nutritional supplement by diabetic patients to antagonize oxidative stress and insulin resistance.

\section{Conflict of interest statement}

No conflict of interest.

\section{Research Ethics Committee Permission}

The current research workis permitted to be executed a ccording to sta ndards of Res earch Ethics committee, Faculty of Veterinary Medicine, Mansoura University.

\section{Authors 'contribution}

N.M conducted experimental protocol and drafted the manuscript; M.F. conducted the statistical a nalysis and revised the manuscript; Y.E. revised the manuscript; Gehad Ramadan revised the manuscript.

\section{REFERENCES}

[1] Wright SM, Aronne U. Causes of obesity. Abdom Radiol. 2012;37:730-2. https://doi.org/10.1007/s00261-012-9862-x 
[2] Rega-Kaun G, Kaun C, Wojta J. More than a simple storage organ: adipose tissue as a source of adipokines involved in cardiovascula $r$ disease. Thromb Haemost. 2013;110:641-50. https://doi.org/10.1160/TH13-03-0212

[3] Preis SR, Massaro JM, Robins SJ, Hoffmann U, Vasan RS, Irlbeck T, et al. Abdominal subcutaneous and visceral adipose tissue and insulin resistance in the Framingham heart study. Obes. 2010;18:2191-8. https://doi.org/10.1038/oby.2010.59

[4] Montague CT, O'Rahilly S. The perils of portliness: causes and consequences of visceral adiposity. Diabetes. 2000;49:883-8. https://doi.org/10.2337/diabetes.49.6.883

[5] Frayn K. The glucose-fatty acid cycle: a physiological perspective. Portland Press Limited; 2003. https://doi.org/10.1042/bst0311115

[6] Tuomilehto H, Seppä J, Uusitupa M. Obesity and obstructive sleep apnea-clinical significance of weight loss. Sleep Med Rev. 2013;17:321-9. https://doi.org/10.1016/j.smrv.2012.08.002

[7] Miraj S. A review study of therapeutic effects of Peganum harmala.Der Pharm Lett. 2016;8:161-6.

[8] Herraiz T, González D, Ancín-Azpilicueta C, Arán V, Guillén H. $\beta$-Carboline alkaloids in Peganum harmala and inhibition of human monoamine oxidase (MAO). Food Chem Toxicol. 2010;48:839-45. https://doi.org/10.1016/j.fct.2009.12.019

[9] Asgarpanah J, Ramezanloo F. Chemistry, pharmacology and medicinal properties of Peganum harmala L. Afr J Pharm Pharmco. 2012;6:1573-80. https://doi.org/10.5897/AJPP11.876

[10] Waki H, Park KW, Mitro N, Pei L, Damoiseaux R, Wilpitz DC, et al. The small molecule harmine is an antidiabetic cell-type-specific regulator of PPARy expression. Cell Metab. 2007;5:357-70. https://doi.org/10.1016/j.cmet. 2007.03.010

[11] Evans RM, Barish GD, Wang Y-X. PPARs and the complex journey to obesity. Nat Med. 2004;10:355. https://doi.org/10.1038/nm1025

[12] Meadus, W., A semi-quantitative RT-PCR method to measure thein vivo effect of dietary conjugated linoleic acid on porcine muscle PPAR gene expression. Biological procedures online, 2003. 5(1): p. 20-28. https://doi.org/10.1251/bpo43

[13] Yuan M, Lin Y. Model selection and estimation in regression with grouped variables. J R Stat Soc B. 2006;68:49-67. https://doi.org/10.1111/j.1467-9868.2005.00532.x
[14] Zainuddin A, Chua KH, Rahim NA, Makpol S. Effect of experimental treatment on GAPDH mRNA expression as a housekeeping gene in human diploid fibroblasts. BMC Mol Biol. 2010;11:59. https://doi.org/10.1186/1471-2199-11-59

[15] Berger JP, Akiyama TE, Meinke PT. PPARs: therapeutic targets for metabolic disease. Trends Pharmacol Sci. 2005;26:244-51. https://doi.org/10.1016/j.tips.2005.03.003

[16] Kasuga M. Insulin resistance and pancreatic $\beta$ cell failure. J Clin Invest 2006;116:1756-60. https://doi.org/10.1172/JCI29189

[17] Selph S, Dana T, Bougatsos C, Blazina I, Patel H, Chou R. Screening for Abnormal Glucose and Type 2 Diabetes Mellitus. 2015 https://doi.org/10.7326/L15-5153-2

[18] Knowler WC, Barrett-Connor E, Fowler SE, Hamman RF, Lachin JM, Walker EA, et al. Reduction in the incidence of type 2 diabetes with lifestyle intervention or metformin. N Engl J Med. 2002;346:393-403. https://doi.org/10.1056/NEJMoa012512

[19] Jackness C, Karmally W, Febres G, Conwell IM, Ahmed L, Bessler M, et al. Very Low-Calorie diet mimics the early beneficial effect of Rouxen-Y gastric bypass on insulin sensitivity and $\beta$-cell function in type 2 diabetic patients. Diabetes. 2013;62:3027-32. https://doi.org/10.2337/db12-1762

[20] Nafisi S, Asghari M, Nezhadi M, Ekhtiari M. Possible antidiabetic effect of Peganum harmala on streptozocine-induced mouse. World Appl Sci J. 2011;14:822-4.

[21] Hussain Z, Waheed A, Qureshi RA, Burdi DK, Verspohl EJ, Khan N, et al. The effect of medicinal plants of Islamabad and Murree region of Pakistan on insulin secretion from INS-1 cells. Phytotherap Res. 2004;18:73-7. https://doi.org/10.1002/ptr.1372

[22] Berrougui $H$, Isabelle $M$, Cloutier $M$, Hmamouchi $M$, Khalil A. Protective effects of Peganum harmala $L$. extract, harmine and harmaline against human low-density lipoprotein oxidation. J Pharm pharmacol 2006;58:967-74. https://doi.org/10.1211/jpp.58.7.0012

[23] Hayet E, Maha M, Mata M, Mighri Z, Laurent G, Mahjoub A. Biological activities of Peganum harmala leaves. Afr J Biotechnol. 2010;9:8199 205. https://doi.org/10.5897/AJB10.564

[24] He W, Barak Y, Hevener A, Olson P, Liao D, Le J, et al. Adipose-specific peroxisome proliferator-activated receptor $\gamma$ knockout causes insulin resistance in fat and liver but not in muscle.PNA S. 2003;100:15712 7. https://doi.org/10.1073/pnas. 2536828100 